University of Nebraska - Lincoln

DigitalCommons@University of Nebraska - Lincoln

\title{
Enhanced bioremediation of soil containing 2,4-dinitrotoluene by a genetically modified Sinorhizobium meliloti
}

Sisir K. Dutta

Howard University

Gail P. Hollowell

Howard University

Fawzy M. Hashem

United States Department of Agriculture

L. David Kuykendall

United States Department of Agriculture

Follow this and additional works at: https://digitalcommons.unl.edu/usdaarsfacpub

Part of the Agricultural Science Commons

Dutta, Sisir K.; Hollowell, Gail P.; Hashem, Fawzy M.; and Kuykendall, L. David, "Enhanced bioremediation of soil containing 2,4-dinitrotoluene by a genetically modified Sinorhizobium meliloti" (2003). Publications from USDA-ARS / UNL Faculty. 358.

https://digitalcommons.unl.edu/usdaarsfacpub/358

This Article is brought to you for free and open access by the U.S. Department of Agriculture: Agricultural Research Service, Lincoln, Nebraska at DigitalCommons@University of Nebraska - Lincoln. It has been accepted for inclusion in Publications from USDA-ARS / UNL Faculty by an authorized administrator of DigitalCommons@University of Nebraska - Lincoln. 


\title{
Enhanced bioremediation of soil containing 2,4-dinitrotoluene by a genetically modified Sinorhizobium meliloti
}

\author{
Sisir K. Dutta ${ }^{\mathrm{a}, *}$, Gail P. Hollowell ${ }^{\mathrm{a}}$, Fawzy M. Hashem ${ }^{\mathrm{b}}$, L. David Kuykendall ${ }^{\mathrm{c}}$ \\ ${ }^{a}$ Department of Biology, Howard University, 415 College Street, Washington, DC 20059, USA \\ ${ }^{\mathrm{b}}$ Sustainable Agriculture Systems Laboratory, Agricultural Research Service, US Department of Agriculture, Beltsville, MD 20705, USA \\ ${ }^{\mathrm{c}}$ Molecular Plant Pathology Laboratory, Agricultural Research Service, US Department of Agriculture, Beltsville, MD 20705, USA
}

Received 3 April 2002; received in revised form 8 November 2002; accepted 2 December 2002

\begin{abstract}
The symbiotic nitrogen-fixing soil bacterium, Sinorhizobium meliloti, is well known for its ability to interact with the leguminous plant Medicago sativa L. It has, however, not been reported that this species possesses the capability to degrade toxic nitroaromatic compounds, such as 2,4-dinitrotoluene (DNT) which is commonly associated with the degradation of the explosive trinitrotoluene (TNT). In this study, the pJS1 DNT-biodegradative plasmid was genetically transferred to S. meliloti strain USDA 1936, which was confirmed by plasmid profile analysis. Several standard analytical and chemical tests including high performance liquid chromatography $(\mathrm{HPLC})$, nitrite $\left(\mathrm{NO}_{2}\right)$ release assays, rhizosphere population and plant greenhouse studies were conducted to test the ability of $S$. meliloti to degrade 2,4-DNT. The possible presence of 2,4-DNT remaining in the treated soil was tested, and no 2,4-DNT had been absorbed by the soil. The pJS1-carrying recombinant strain DHK1 produced 'ARC' alfalfa plants that were almost 2-fold higher in shoot dry weight than that produced by the parent strain on soil containing $0.14 \mathrm{mM}$ 2,4-DNT. The transconjugant strain DHK1 reduced significantly one-third more 2,4-DNT in both 0.14 and $0.28 \mathrm{mM}$ contaminated soil, and in $0.55 \mathrm{mM}$ contaminated soil it degraded $94 \%$ of the 2,4-DNT present. In liquid cultures, however, only about $4 \%$ reduction in 2,4-DNT concentrations was obtained in 10 days. We interpret the results as clearly establishing that genetic modification was successfully used, for the first time, to improve the capability of the symbiotic nitrogen-fixing soil bacterium $S$. meliloti DHK1 to bioremediate in situ 2,4-DNT-contaminated soil in the presence of alfalfa plants.
\end{abstract}

(C) 2003 Elsevier Science Ltd. All rights reserved.

Keywords: Genetic transfer; Alfalfa; Medicago sativa L; Rhizosphere; Plasmid analysis

\section{Introduction}

2,4,6-Trinitrotoluene (TNT) is primarily manufactured for use by the military. Two products derived from TNT are 2,4-dinitrotoluene (DNT) and toluene. These toxic aromatic compounds and other metabolites, such as benzene, ethylbenzene and xylenes are manufactured for use in fertilizers, herbicides, and pesticides, as well as in the production of plastics and dyes (Spanggord et al., 1991; Duque et al., 1993). These toxic compounds occur widespread in the environment as a result of agricultural runoff, industrial wastes sites, and military operations (Duque et al., 1993) and thus are significant environmental pollutants of considerable concern. According to the US Environmental Protection Agency (EPA), chemical manufacturers and

\footnotetext{
* Corresponding author. Tel.: + 1-202-806-6942; fax: + 1-202-806-5832. E-mail address: sdutta@howard.edu (S.K. Dutta).
}

petroleum refineries in the US generate millions of tons of TNT, DNT and toluene annually (Keith and Telliard, 1979; Hanson, 1990). The EPA lists these compounds as hazardous wastes (Hanson, 1990).

Bioremediation is the process of cleaning up hazardous wastes with microorganisms or plants and is the safest method of clearing soil of pollutants (Alleman and Leeson, 1997). The chief concern of bioremediation research on soil contaminated with toxic chemicals is the removal of, and/or reduction in, the amount of toxic substances so that neither soil nor water is harmful to animals, humans, plants, or beneficial microbes. In soil, toxic aromatic hydrocarbons may sometimes exist in an adsorbed state but nevertheless may still participate in chemical reactions and can be subject to bioremediation.

Plants absorb nutrients from soil in water-soluble form by virtue of their root systems (Leeson and Alleman, 1999). 
Many leguminous plants and particularly alfalfa have extensive soil-root systems extending as deep as $2 \mathrm{~m}$. Rhizosphere, or soil-root, systems limit the diffusion of solutes in the soil. Hence, the plant can serve both as a vehicle for limiting the spread of solutes and by promoting the mineralization of the toxic compound. The general feasibility of rhizosphere approaches to remediation has been previously demonstrated (Anderson and Coats, 1994).

Genome sequencing of the symbiotic nitrogen-fixing soil bacterium Sinorhizobium meliloti strain 1021 has been reported (Galibert et al., 2001), and it seems to have probable dioxygenase and monooxygenase genes (Dutta et al., unpublished data). Recently Labidi et al. (2001) have reported that Gram-negative bacteria of the family Rhizobiaceae, including $S$. meliloti (formerly Rhizobium meliloti (Kuykendall et al., 2003) can reduce the nitroaromatic compound TNT into amino-DNT. Bacteria of the genus Sinorhizobium have highly evolved symbiotic relationships with leguminous plants, including alfalfa, Medicago sativa L. and soybean, Glycine max (L.) Merr. (Hashem et al. 1997; Kuykendall et al., 1999). These symbiotic relationships occur in root nodules of leguminous plants, where the microsymbionts transform atmospheric nitrogen into amino acids needed for plant growth. According to Kuykendall et al. (1997) the soil bacterium $S$. meliloti, a microsymbiont of alfalfa plants, is a good candidate for genetic modification to bioremediate contaminated soils. Earlier research conducted in our laboratories successfully transferred and expressed the TOL plasmid in S. meliloti (Hollowell et al., 1999; Kuykendall et al., 1997). These studies more than justified our use of this particular plant-associated soil bacterium for the research herein described.

S. meliloti is a motile, rod-shaped bacterium which naturally lives as a microbial constituent of soil microbial populations and this particular species has evolved an intimate symbiotic relationship with alfalfa. Additionally, these bacteria are more amenable to genetic manipulation than many other legume-nodulating bacterial species (Kuykendall et al., 1997). Therefore, the primary goal of this research was to genetically modify the nitrogen-fixing microsymbiont (S. meliloti strain USDA 1936) for enhanced rhizosphere bioremediation of TNT. Plasmid pJS1, comprising the 2,4-DNT gene cluster, carries genes encoding enzymes for DNT degradation (Suen and Spain, 1993). Although this plasmid had been studied, it had not yet been transferred to legume microsymbionts such as those in the genus Sinorhizobium.

This paper presents data on the intergeneric transfer of plasmid pJS1 to S. meliloti strain USDA 1936 from Burkholderia sp. strain DNT. The pJS1 plasmid carries all of the necessary genes for 2,4-DNT degradation, and therefore also herein describe our investigation of the role of this novel intergeneric transconjugant in the biodegradation of 2,4-DNT vis-à-vis the alfalfa/S. meliloti symbiosis.

\section{Materials and methods}

\subsection{Host/strain selection}

Individually, three S. meliloti strains USDA 1936, USDA 1954 and USDA 1969 were used to inoculate several alfalfa cultivars in a greenhouse experiment to determine the interaction of $S$. meliloti strains with diverse alfalfa genotypes. Plant height and healthy dark green color were the main distinguishing physical characteristics of plants, grown without combined nitrogen, used to determine the optimal host genotype/bacterial strain combination. Acetylene reduction assay was used to estimate nitrogenase activity, another measure of the effectiveness of the symbioses formed. Based on these assays and the research findings of Hashem et al. (1997) and Kuykendall et al. (1999), the alfalfa cultivar used as host for S. meliloti USDA 1936 was $M$. sativa L. cv. 'ARC', a USDA-developed cultivar with multiple pest resistance (Devine et al., 1975), which exhibits with strain USDA 1936 in particular a highly competent symbiotic interaction capable of fixing lots of nitrogen. Thus, S. meliloti strain USDA 1936 and ARC alfalfa were selected as the optimal host/strain combination used in our subsequent studies.

\subsection{Bacteria}

Burkholderia sp. strain DNT, containing genes for 2,4-DNT degradation (pJS1) was supplied by Dr J. C. Spain, Air Force Civil Engineering Support Agency, Tyndall Air Force Base, Florida (Suen and Spain, 1993; Suen et al., 1996). S. meliloti strains USDA 1936, USDA 1954 and USDA 1969 were obtained from Dr Peter van Berkum, Soybean Genomics and Improvement Laboratory, Beltsville Agricultural Research Center (BARC), USDA, Beltsville, Maryland 20705. Also at BARC, Dr Tom E. Devine of the Sustainable Agricultural Systems Laboratory generously provided seed of alfalfa, $M$. sativa $\mathrm{L}$., cv ARC. Descriptions of bacterial growth media and the maintenance of different bacterial cultures are provided in the following sections.

\subsection{Gene transfer experiments}

Donor (Burkholderia sp. strain DNT) and recipient (S. meliloti $\mathrm{Rif}^{\mathrm{R}}$ ) strains were grown in Kuykendall-O'Neill (KO) medium (Kuykendall and Elkan, 1976; Gillette and Elkan, 1996), overnight in a $30^{\circ} \mathrm{C}$ shaking incubator (100 rpm). The composition of the inorganic basal salts was originally from Cole and Elkan (1973). Intergeneric matings were performed by incubating the pellets obtained from centrifuging equal volumes from the donor and recipient cultures for at least $2 \mathrm{~h}$ at $30^{\circ} \mathrm{C}$, and then spreading aliquots of a dense resuspension of cells $\left(1 \times 10^{9} \mathrm{CFU} \mathrm{ml}{ }^{-1}\right)$ onto $\mathrm{KO}$ selective growth medium described below. 
Table 1

Mobilization of 2,4-DNT plasmids between bacterial genera

\begin{tabular}{|c|c|c|}
\hline Donor & Recipient & Transconjugant \\
\hline Burkholderia sp. strain & S. meliloti USDA & S. meliloti USDA \\
\hline $\begin{array}{l}\text { DNT possessing } \\
\mathrm{Tc}^{\mathrm{R}} \text {, carrying 2,4-DNT } \\
\text { degradative genes (pJS1, } \\
\text { pJS2, and pJS3) }\end{array}$ & $1936 \mathrm{Rif}^{\mathrm{R}}, \mathrm{Nal}^{\mathrm{R}}$ & $\begin{array}{l}1936 \mathrm{Rif}^{\mathrm{R}}, \mathrm{Nal}^{\mathrm{R}}, \\
\mathrm{Tc}^{\mathrm{R}}(\mathrm{pJS} 1)\end{array}$ \\
\hline
\end{tabular}

$\mathrm{Rif}^{\mathrm{R}}$, rifampicin resistant; $\mathrm{Tc}^{\mathrm{R}}$, tetracycline resistance; $\mathrm{Nal}^{\mathrm{R}}$, nalixidic acid resistance.

Alternatively, control plates and mixtures containing donor (500 $\mu$ l of Burkholderia sp. culture) and recipient cells $(500 \mu \mathrm{l}$ of $S$. meliloti culture) spread onto plates were incubated at $30{ }^{\circ} \mathrm{C}$ for at least $16 \mathrm{~h}$ prior to their resuspension and plating onto selective media (Kuykendall, 1979).

\subsection{Verification of bacterial recombinants}

Transconjugants carrying pJS1 were selected on agar medium containing rifampicin $\left(150 \mu \mathrm{g} \mathrm{ml}^{-1}\right)$ and crystalline 2,4-DNT. Rifampicin eliminated the donor bacterium; Burkholderia sp. DNT and 2,4-DNT selected for pJS1-carrying recombinant Sinorhizobium cells. Recombinants were verified using nalidixic acid $\left(200 \mu \mathrm{g} \mathrm{ml}^{-1}\right)$ resistance $\left(\mathrm{Nal}^{\mathrm{R}}\right)$ on agar medium, a non-selected natural marker of the $S$. meliloti genome (Table 1).

\subsection{Molecular evidence}

\subsubsection{Plasmid DNA isolation}

A modified protocol for purified plasmid DNA isolation was used (Itoh et al., 1984). The cells were harvested by centrifugation at $4{ }^{\circ} \mathrm{C}, 6000 \mathrm{~g}$ for $10 \mathrm{~min}$ using a Sorvall RC-5B, GS-3 rotor. The pellets were resuspended in $8 \mathrm{ml}$ of $50 \mathrm{mM}$ Tris $-\mathrm{HCl}(\mathrm{pH}$ 8.0) containing $25 \%$ (w/v) sucrose. Cells and all reagents were maintained on ice. The following solutions: (I) $1.2 \mathrm{ml}$ lysozyme solution $[20 \mathrm{mg} / \mathrm{ml}$ in $0.25 \mathrm{M}$ Tris-HCl (pH 8.0)]; (II) $8 \mathrm{ml}$ of $0.25 \mathrm{M}$ EDTA (pH 8.0); (III) $12 \mathrm{ml}$ of $1.0 \%(\mathrm{w} / \mathrm{v})$ Brij35, 0.4\% (w/v) sodium deoxycholate in $10 \mathrm{mM}$ Tris-HCl, $1 \mathrm{mM}$ EDTA (pH 8.0) were added to the resuspended pellet, and after each solution was added, the tubes were mixed by swirling. The samples were left on ice for $30 \mathrm{~min}$ and then centrifuged at $4{ }^{\circ} \mathrm{C}$, $23,420 \mathrm{~g}$ for $90 \mathrm{~min}$ using a Sorvall RC-5B, Type SS-34 rotor. The supernatant was carefully decanted into a set of fresh tubes and 1/5 volume of polyethylene glycol (PEG) solution [50\% (w/v) PEG 8000, 15\% (w/v) NaCl] was added to each tube and mixed by gentle inversion. Following an overnight incubation at $4{ }^{\circ} \mathrm{C}$, the DNA was pelleted by a low-speed centrifugation at $4{ }^{\circ} \mathrm{C}, 10,000 \mathrm{~g}$ for 10 min using a Sorvall RC-5B, Type SS-34 rotor. The pellet was redissolved in $10.3 \mathrm{ml}$ Tris EDTA salt (TES) [50 mM Tris-HCl, $5 \mathrm{mM}$ EDTA, $50 \mathrm{mM} \mathrm{NaCl}$ (pH 8.0)] buffer on an orbital shaker for $1 \mathrm{~h}$. Using the same tubes, $11.4 \mathrm{~g}$ of $\mathrm{CsCl}$ and $300 \mu \mathrm{l}$ of $1.0 \%$ of $\mathrm{EtBr}$ was added. The tubes were mixed gently and then incubated on ice for $1 \mathrm{~h}$. The tubes were centrifuged at $4{ }^{\circ} \mathrm{C}, 11,950 \mathrm{~g}$ for $15 \mathrm{~min}$ and the flocculent PEG precipitant was removed using a cotton swab. Isopycnic ultracentrifugation was performed at $18{ }^{\circ} \mathrm{C}$, 204,000 $\mathrm{g}$ for $18 \mathrm{~h}$ using a Beckman L2-65B, Type 50Ti rotor. The lower band (plasmid DNA) was carefully collected using $18^{\prime \prime}$ gauge needle and syringe. Ethidium bromide was removed by three extractions with $n$-butanol that had been equilibrated against saturated $\mathrm{CsCl}$ solution in TES buffer. The plasmid DNA was dialyzed against three $1-21$ changes of deionized water $\left(\mathrm{dH}_{2} \mathrm{O}\right)$. Dilutions (1:20) and absorbance readings $(260 \mathrm{~nm})$ were made of each sample to approximate the concentration of DNA in the original sample. The samples were stored at $-20{ }^{\circ} \mathrm{C}$ until ready for use.

\subsubsection{Analysis of plasmids}

S. meliloti strain USDA 1936 transconjugant pJS1, from now on referred to simply as strain DHK1, was confirmed by plasmid analysis, using a modified Eckhardt electrophoresis procedure (Hashem and Kuykendall, 1994). Cultures were grown overnight in a $30^{\circ} \mathrm{C}$ shaker incubator. Gels were prepared in $1 \times$ Tris Borate EDTA (TBE) buffer with $0.75 \%(w / v)$ agarose and $1.0 \%(w / v)$ sodium didocyl sulfate (SDS). Two hundred microliters of each sample were pipetted into eppendorf tubes on ice. To each sample, $1 \mathrm{ml}$ of cold $0.3 \%$ sodium lauroyl sarkosinate (sarkosyl) was added and kept on ice for $10 \mathrm{~min}$. The cells were pelleted by centrifugation (about $17,000 \mathrm{~g}$ for $5 \mathrm{~min}$ at $4{ }^{\circ} \mathrm{C}$ ), resuspended in $25 \mu \mathrm{l}$ of lysis solution and immediately loaded into the gel. In short, the modified Eckhardt gel electrophoresis is an in-well cell lysis procedure that permits the separation of extremely large $(>1 \mathrm{Mb})$ megaplasmids, as well as large molecular weight $(200-1000 \mathrm{~kb})$ plasmids (Hashem and Kuykendall, 1994).

\subsection{Utilization of 2,4-DNT by S. meliloti transconjugants}

\subsubsection{Liquid culture experiments}

S. meliloti USDA 1936 and transconjugant S. meliloti DHK1 were grown for 10 days in $\mathrm{KO}$ medium on a $30^{\circ} \mathrm{C}$ shaker incubator (100 rpm). Based on an initial absorbance reading of $0.100(595 \mathrm{~nm}), 100 \mu \mathrm{l}$ of inoculum from each of these cultures was added to $100 \mathrm{ml}$ of $\mathrm{KO}$ medium in the presence and absence of $0.14 \mathrm{mM}\left(25 \mu \mathrm{g} \mathrm{ml}^{-1}\right) 2,4-\mathrm{DNT}$. On days 3, 6, and 10, optical density (OD) readings were taken and extractions were performed on the culture supernatant. The methodologies for liquid extraction and HPLC analysis are described under collection of metabolites and HPLC analysis, respectively.

\subsubsection{Protein assays}

Aliquots $(1 \mathrm{ml})$ were removed from the liquid culture suspensions on days $0,3,6$, and 10 over a 10 -day period. 
These aliquots were spun at about $5000 \mathrm{~g}$ for $5 \mathrm{~min}$. Supernatant samples were assayed for protein determination by combining $100 \mu \mathrm{l}$ of each to $900 \mu \mathrm{l}$ of Bio-Rad protein dye (Bradford, 1976). Protein concentration of each sample was estimated by measuring the absorbance at $595 \mathrm{~nm}$ and converting the OD readings to $\mathrm{mg} \mathrm{ml}^{-1}$ by reference to a standard bovine serum albumin (BSA) curve. All protein concentrations were determined by solving for the slope intercept using a best-fit standard curve.

\subsubsection{Soil absorption experiments}

Soil absorption experiments were conducted to determine whether nitroaromatic compound $(2,4-\mathrm{DNT})$ would bind to the soil matrix in the plant experiments. To $5 \mathrm{~g}$ of sterile soil amended with or without 2,4-DNT, $20 \mathrm{ml}$ of methanol was added and this mixture was allowed to shake overnight in a $30{ }^{\circ} \mathrm{C}$ incubator. As a result, soil extractions and HPLC analysis were performed to determine the percent recovery of 2,4-DNT from contaminated soil. The methodologies for soil extraction and HPLC analysis are described under collection of metabolites and HPLC analysis, respectively.

\subsubsection{Plant experiments}

Alfalfa (M. sativa L. cv. ARC) seeds were grown in Leonard jars (Leonard, 1943) filled with an autoclaved $\left(2 \mathrm{~h}\right.$ at $\left.121^{\circ} \mathrm{C}\right)$ soil-vermiculite $(1: 1)$ mixture containing 2,4-DNT $\quad\left\{0.055 \mathrm{mM} \quad\left(10 \mu \mathrm{g} \mathrm{g}^{-1}\right) \quad\right.$ and $\quad 0.55 \mathrm{mM}$ $\left.\left(100 \mu \mathrm{g} \mathrm{g}^{-1}\right)\right\}$. Before planting, seeds were surface-sterilized in $70 \%$ ethanol (30 s), sterile $\mathrm{dH}_{2} \mathrm{O}$ (1 min), $\mathrm{H}_{2} \mathrm{O}_{2}$ ( $5 \mathrm{~min}$ ), and rinsed thoroughly 2 times in sterile $\mathrm{dH}_{2} \mathrm{O}$ (2 min) (Somasegaran and Hoben, 1994). Except for the uninoculated controls, seeds were inoculated with $1.0 \mathrm{ml}$ (containing about $1 \times 10^{9}$ cells) of a 2-day-old culture of S. meliloti. Plants were initially supplied with sterile water, followed by the addition of nitrogen-free Norris plant nutrient solution (Norris, 1964) as needed. These plant experiments were carried out in a controlled temperature growth chamber environment set with a $16 \mathrm{~h}$ (1:1) fluorescent-incandescent light period at $30{ }^{\circ} \mathrm{C}$, and an $8 \mathrm{~h}$ dark period at $22{ }^{\circ} \mathrm{C}$. Plants were grown for 6 weeks before harvesting. At the end of 6 weeks, both shoot dry weight and number of nodules were determined. Nitrogenase activities, at the time of harvest, were also determined using acetylene reduction assays as described by Sloger (1969). Bacteria recovered from nodules were streaked onto $\mathrm{KO}$ medium containing rifampicin $\left(150 \mu \mathrm{g} \mathrm{ml}^{-1}\right)$.

\subsubsection{Acetylene reduction}

Upon harvesting the growth chamber plant experiments, the roots were excised from the plants, rinsed off with water, and placed in a tightly sealed jar. In the cap of each jar there was a rubber stopper through which $10 \%$ acetylene was injected to start the assay. After each acetylene injection, the jars were incubated for $30 \mathrm{~min}$ at room temperature $\left(25 \pm 2^{\circ}\right)$ to allow time for the reaction to occur.
Duplicate samples from each jar were analyzed for ethylene production by gas chromatography (Kummer and Kuykendall, 1989; Myrold, 1997) to complete the assay. Appropriate dilutions of pure ethylene were also analyzed by gas chromatography to produce a standard curve.

\subsubsection{Soil bacteria recovery}

Upon harvesting the plant experiment, $2.0 \mathrm{~g}$ of soil were added to $5 \mathrm{ml}$ of $\mathrm{dH}_{2} \mathrm{O}$ and allowed to incubate overnight at $30{ }^{\circ} \mathrm{C}$ in a shaker incubator $(100 \mathrm{rpm})$. After allowing about $4 \mathrm{~h}$ for the phases to separate, $100 \mu \mathrm{l}$ of the supernatant was diluted (1:10) and plated on selective TY plates, and then incubated for 2 days at $30^{\circ} \mathrm{C}$, thus verifying the presence of the recombinant bacteria (Dandurand and Knudsen, 1997). This method of determining CFUs from the rhizosphere was used to estimate number of bacteria capable of survival in contaminated soils.

\subsubsection{Nitrite assay}

To detect the release of nitrite from 2,4-DNT in contaminated soil that had been inoculated with $S$. meliloti cultures, at the time of harvest $2 \mathrm{~g}$ of soil were removed from the rhizosphere of each Leonard jar. Deionized water $(5 \mu 1)$ was added to each sample and mixed gently. The samples were then spun at $5049 \mathrm{~g}$ for $5 \mathrm{~min}$. The test procedure for nitrite release is essentially as described by Jackson et al. (1999). Supernatant samples were assayed for the presence of nitrite by combining $0.5 \mathrm{ml}$ of each supernatant to $0.5 \mathrm{ml}$ of $1 \%(\mathrm{w} / \mathrm{v})$ sulfanilamide in $1.5 \mathrm{~N}$ $\mathrm{HCl}$ and $0.5 \mathrm{ml}$ of $0.02 \%(\mathrm{w} / \mathrm{v}) \mathrm{N}$-1-naphthyl ethylenediamine (Daniels et al., 1994). Nitrite release from each sample was estimated by measuring the absorbance at $540 \mathrm{~nm}$ and converting the OD readings to $\mu \mathrm{g} \mathrm{ml}^{-1}$ by re ference to a standard curve.

\subsubsection{Collection of metabolites}

In liquid culture experiments, cells grown aerobically in $\mathrm{KO}$ broth at $30{ }^{\circ} \mathrm{C}$ for $48 \mathrm{~h}$ were removed by centrifugation at about $5000 \mathrm{~g}$ for $10 \mathrm{~min}$. Upon harvesting the plant experiments, an equal ratio (w/v) of soil and methanol were mixed together. This mixture was diluted with an equal volume of water, mixed gently, and spun at about $5000 \mathrm{~g}$ for $5 \mathrm{~min}$ to pellet the sediment. In the soil experiments, $20 \mathrm{ml}$ of supernatant was added to 4-fold volume of methylene chloride for extraction. The organic layer was filtered though sodium sulfate on a filter paper in a funnel to remove residual soil particles, then $50 \mathrm{ml}$ of the solvent was evaporated using a rotary evaporator under reduced pressure at $42{ }^{\circ} \mathrm{C}$. Lastly, metabolites were dissolved in $1.0 \mathrm{ml}$ of methanol and filtered though a $0.45 \mu \mathrm{m}$ nylon membrane filter syringe (Daniels et al., 1994).

\subsubsection{High performance liquid chromatography}

Upon harvesting the plants, 2,4-DNT was extracted from soil using methylene chloride. Evaporation was used to concentrate the samples; $5 \mu \mathrm{l}$ of each were analyzed by 
HPLC using a $150 \times 4.6 \mathrm{~mm}^{2}$ SUPELCO Supelcosil LC-18 column. A mobile phase of water-methanol (54:46), flow rate of $1.0 \mathrm{ml} \mathrm{min}$, and a wavelength of $254 \mathrm{~nm}$ were used to detect the compound on a Hewlett-Packard Series 1050 UV-visible detector as described by Dutta et al. (1998). 2,4-DNT was identified by the retention time of a TNT standard. The concentration of 2,4-DNT was identified using a standard curve.

\subsubsection{Statistical analyses}

All tests were performed in triplicate and thus the mean \pm standard deviation was calculated. Data were analyzed by analysis of variance $(P \leq 0.05)$ using the statistical analysis system (Goodnight, 1982.)

\section{Results}

\subsection{Host/strain selection}

Based on an in-well lysis and gel electrophoresis, S. meliloti strain USDA 1936, S. meliloti USDA 1954, and S. meliloti USDA 1969 had two mega-sized (Sym) plasmids (Fig. 1) (Galibert et al., 2001). Plant vigor, evidenced by height and color were the most important factors in determining the optimal host/strain combination. Using all of this collective information $S$. meliloti USDA 1936 and ARC alfalfa seeds were chosen as the optimal strain/host combination to be used in the subsequent studies.

\subsection{Bacterial recombinants}

Table 1 summarizes mobilization of the 2,4-DNT plasmid between bacterial genera. Using standard conjugation, it was possible to successfully transfer the pJS1 plasmid to S. meliloti strain USDA 1936. This data show the transfer of the Burkholderia sp. DNT gene cluster containing plasmid pJS1 (containing all the necessary genes for complete degradation of 2,4 DNT) to $S$. meliloti USDA 1936.

Plasmid analysis was done to identify plasmids in the Sinorhizobium transconjugants (Fig. 1), which indicated the insertion of pJS1 plasmid. The molecular weight of the plasmids in S. meliloti USDA 1936 (pJS1) transconjugant was estimated from the wild type genome $S$. meliloti (Galibert et al., 2001). The molecular weight of the plasmid introduced into S. meliloti USDA 1936 (pJS1) transconjugant, was smaller than the resident megaplasmids in the parental recipient strain. These results are conclusive since the parental strain lacks the plasmid found in the transconjugant.

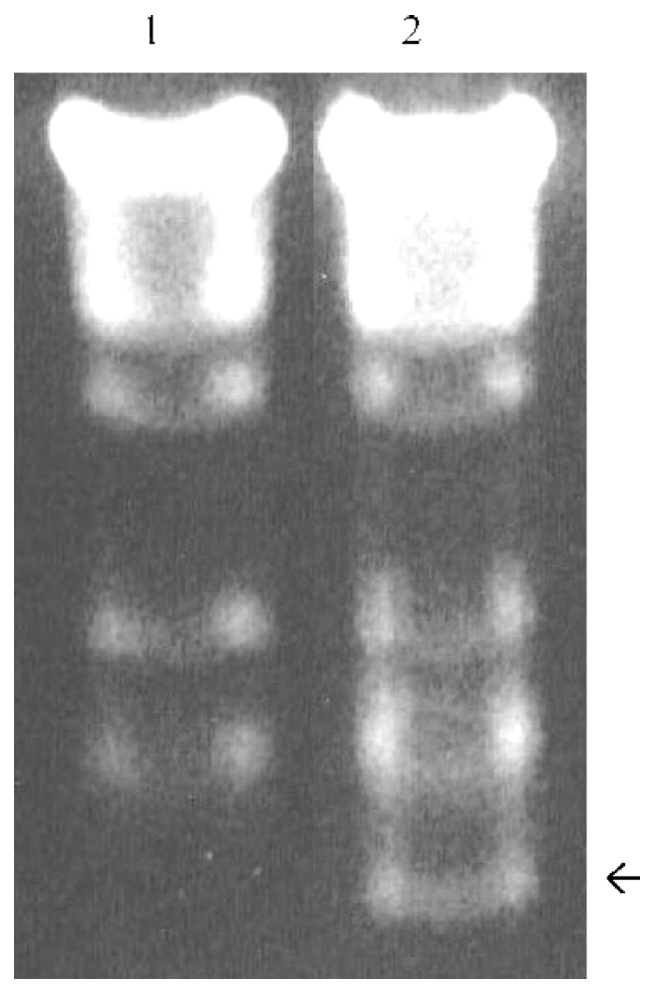

Fig. 1. Plasmid sizes of $S$. meliloti wild type vs. those of transconjugant DHK1. Lane 1 shows plasmid profiles of wild type S. meliloti USDA 1936 showing chromosomal DNA (3.6 Mb) and two plasmid DNA (1.68 Mb and $1.35 \mathrm{Mb}$ ) as described by Galibert et al. (2001). Lane 2 is $S$. meliloti USDA 1936 transconjugant showing all the DNA bands as in wild type and in addition shows the insert (pJS1) of approx. $0.18 \mathrm{Mb}$ (indicated by arrow).

\subsection{Liquid culture experiments}

\subsubsection{Expression of 2,4-DNT gene( $s$ ) in transconjugant DHK1}

A final concentration of $0.14 \mathrm{mM} 2,4-\mathrm{DNT}$ was added to KO liquid culture containing either the $S$. meliloti strain USDA 1936 parent or DHK1. On days 3, 6 and 10 the supernatant from the cultures were tested for primary degradation of 2,4-DNT by HPLC analysis (Table 2). The transconjugant DHK1 reduced 2,4-DNT by $5.6 \pm 2.4$, $4.9 \pm 4.0$ and $4.2 \pm 2.0 \%$, respectively, at $0.14 \mathrm{mM}$ 2,4-DNT concentrated in liquid culture. Incubation time, however, had no significant effect on 2,4-DNT in liquid culture (Table 2). Compared to $0 \%$ reduction of 2,4-DNT by

Table 2

2,4-DNT reduction in liquid culture determined by HPLC analysis

\begin{tabular}{llll}
\hline 2,4-DNT Concentration & \multicolumn{2}{l}{ Reduction (\%) } \\
\cline { 2 - 4 } $0.14 \mathrm{mM}$ & Day 3 & Day 6 & Day 10 \\
\hline Uninoculated & 0 & 0 & 0 \\
$\begin{array}{l}\text { Inoculated with S. meliloti } \\
\text { USDA 1936 }\end{array}$ & 0 & 0 & 0 \\
$\begin{array}{l}\text { Inoculated with transconjugant } \\
\text { DHK1 }\end{array}$ & $5.6 \pm 2.4$ & $4.9 \pm 4.0$ & $4.2 \pm 2.0$ \\
\hline
\end{tabular}


Table 3

In situ effect of $S$. meliloti transconjugant DHK1 in various 2,4-DNT soil concentrations on nodulation and growth of ARC alfalfa

\begin{tabular}{llrr}
\hline Strain & Plant color & Shoot dry weight (mg) & Nodule number \\
\hline Uninoculated & Yellow & $21 \pm 4$ & $0 \pm 0$ \\
DHK1 & Dark green & $163 \pm 20$ & $50 \pm 18$ \\
Uninoculated $+0.055 \mathrm{mM}$ & Light green & $32 \pm 10$ & $0 \pm 0$ \\
DHK1 $+0.055 \mathrm{mM}$ & Dark green & $197 \pm 25$ & $60 \pm 21$ \\
Uninoculated $+0.14 \mathrm{mM}$ & Light green & $33 \pm 12$ & $0 \pm 0$ \\
DHK1 $+0.14 \mathrm{mM}$ & Dark green & $172 \pm 22$ & $45 \pm 15$ \\
Uninoculated $+0.28 \mathrm{mM}$ & Light green & $21 \pm 3$ & $0 \pm 0$ \\
DHK1 $+0.28 \mathrm{mM}$ & Green & $99 \pm 15$ & $45 \pm 16$ \\
\hline
\end{tabular}

Values represent mean of ten plants/jar. Plants in $0.55 \mathrm{mM}$ 2,4-DNT soil did not grow.

the non-transconjugant, these low rates were considered measurable reductions, and were consistent in all tests.

\subsection{In situ effect of transconjugant DHK1 in 2,4-DNT soil}

Various 2,4-DNT soil concentrations $(0.055-0.550 \mathrm{mM})$ on plants inoculated with $S$. meliloti transconjugant strain DHK1 indicated that uninoculated alfalfa seeds had less chance for survival in the higher concentrations of 2,4-DNT (Table 3), but inoculated plants maintained high shoot dry weights with moderate concentrations of 2,4-DNT. Present data obtained with soil containing various 2,4-DNT soil concentrations and inoculated with $S$. meliloti USDA 1936 indicated that $0.14 \mathrm{mM}$ was the concentration at which further studies should be conducted. The toxic effects of high 2,4-DNT mM concentrations was shown by plants in $0.55 \mathrm{mM} 2,4-\mathrm{DNT}$ soil that did not grow. This data show that higher the 2,4-DNT concentrations, the more toxic effects to plant growth. Table 4 shows the in situ effect of the S. meliloti transconjugant DHK1 (pJS1plasmid) and at the parental strain USDA 1936 on nodulation and growth of ARC alfalfa grown in 2,4-DNT contaminated soil.
The parental strain 1936 produced about 13-, 4- or 3-fold more nodules than recombinant strain DHK1 on $0,0.14$ or $0.28 \mathrm{mM}$ 2,4-DNT, respectively. However, with $0.14 \mathrm{mM}$ 2,4-DNT, the pJS1-carrying strain DHK1 produced a shoot dry weight that was almost 2-fold higher than that produced by the recombinant strain on soil containing no 2,4-DNT. Evidently at this concentration, 2,4-DNT stimulates symbiotic nitrogen fixation by the recombinant strain carrying pJS1. Without 2,4-DNT present, however, strain DHK1 was impaired symbiotically compared with strain 1936 since the latter doubled the plant shoot dry weight over the uninoculated control and the pJS1-carrying derivative increased plant dry weight by only about $30 \%$.

\subsection{Nitrite assays}

Nitrite assays failed to reveal significant nitrite release from either $S$. meliloti strain USDA 1936 or transconjugant DHK1, presumably due to the conversion of nitrite into nitrate by the $S$. meliloti strains and subsequent utilization by the plants (Table 5).

Table 4

In situ effect of $S$. meliloti transconjugant DHK1 and parental strain 1936 on nodulation and growth of ARC alfalfa grown in 2,4-DNT contaminated soil

\begin{tabular}{|c|c|c|c|c|}
\hline Strain & Plant color & Shoot dry weight & Nodule number & Colony forming units \\
\hline \multicolumn{5}{|l|}{ Untreated } \\
\hline Uninoculated & Yellow & $103 \pm 11$ & $0 \pm 0$ & $0 \pm 0$ \\
\hline Parental strain USDA 1936 & Dark green & $239 \pm 18$ & $269 \pm 20$ & $2.82 \times 10^{5}$ \\
\hline Transconjugant DHK1 & Light green & $131 \pm 12$ & $20 \pm 6$ & $1.59 \times 10^{5}$ \\
\hline \multicolumn{5}{|l|}{$0.14 \mathrm{mM}$} \\
\hline Uninoculated & Light green & $126 \pm 12$ & $0 \pm 0$ & $0 \pm 0$ \\
\hline Parental strain USDA 1936 & Dark green & $221 \pm 17$ & $119 \pm 19$ & $1.14 \times 10^{5}$ \\
\hline Transconjugant DHK1 & Green & $400 \pm 37$ & $33 \pm 8$ & $0.70 \times 10^{5}$ \\
\hline \multicolumn{5}{|l|}{$0.28 \mathrm{mM}$} \\
\hline Uninoculated & Light green & $23 \pm 5$ & $0 \pm 0$ & $0 \pm 0$ \\
\hline Parental Strain USDA 1936 & Green & $139 \pm 15$ & $42 \pm 13$ & $1.07 \times 10^{5}$ \\
\hline Transconjugant DHK1 & Light green & $144 \pm 21$ & $14 \pm 4$ & $0.97 \times 10^{5}$ \\
\hline
\end{tabular}

Values represent mean \pm standard deviation per jar $(n=10$ plants/jar, $p \leq 0.05)$. The higher the 2,4-DNT concentration, the more toxic effects to rhizosphere growth. $0.55 \mathrm{mM} 2,4 \mathrm{DNT}$ was highly toxic to $S$. meliloti growth in the rhizosphere. 
Table 5

Nitrite release from 2,4-DNT soils inoculated with S. meliloti (pJS1)transconjugant, DHK1

\begin{tabular}{ll}
\hline Treatment & Nitrite release $(\mu \mathrm{g} / \mathrm{ml})$ \\
\hline Sterile soil & \\
Uninoculated (no plants) & 0.0 \\
Plants + USDA 1936 & 0.0 \\
Plants + USDA 1936 (pJS1) transconjugant & 0.0 \\
& \\
Non-sterile soil & $0.16 \pm 0.27$ \\
Uninoculated (no plants) & 0.0 \\
Plants + USDA 1936 & 0.0 \\
Plants + USDA 1936 (pJS1) transconjugant & \\
& \\
O.14 mM 2,4-DNT soil & $0.37 \pm 0.44$ \\
Uninoculated (no plants) & $0.07 \pm 0.18$ \\
Plants + USDA 1936 & $0.08 \pm 0.17$ \\
Plants + USDA 1936 (pJS1) transconjugant & \\
\multicolumn{1}{c}{ Values represent mean \pm standard deviation per jar. $n=10$ plants/jar, } \\
$p \leq 0.05$.
\end{tabular}

\subsection{2,4-DNT utilization based on HPLC analysis}

Analysis by HPLC was performed to determine if there was any reduction of 2,4-DNT in the contaminated soils by either the S. meliloti parental strain USDA 1936 or the $S$. meliloti USDA(pJS1) transconjugant strain DHK1. This data show the evidence of 2,4-DNT reduction by transconjugant DHK1 in $0.55 \mathrm{mM}$ 2,4-DNT soil. Transconjugant strain DHK1 reduced 2,4-DNT by $60 \%$ in both 0.14 and $0.28 \mathrm{mM}$ contaminated soil (Fig. 2). Although $0.55 \mathrm{mM}$ 2,4-DNT contaminated soil was evidently too toxic for the plant growth, HPLC analysis was done to determine if there was any utilization of the compound. The result was that transconjugant DHK1 showed a 94\% reduction of 2,4-DNT in $0.55 \mathrm{mM}$ contaminated soil (Fig. 2). In all three conditions reduction of 2,4-DNT was statistically significant $(P \leq 0.05)$ by $S$. meliloti transconjugant as compared with the non-transconjugant, wild-type $S$. meliloti strain USDA 1936.

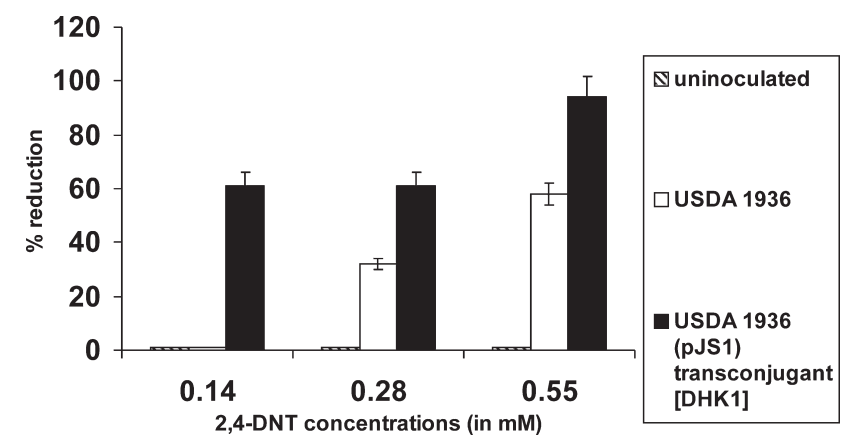

Fig. 2. Histograms of the reduction of 2,4-DNT using trans-conjugant and wild type.

\section{Discussion}

Research on the bioremediation of contaminated soil has as its goal the removal of and/or reduction in the amount of toxic substances in the soil. Most of this research focused in using microorganisms other than nitrogen fixing bacteria for the bioremediation of contaminated soils with nitroaromatic and polychlorinated aromatic compounds (Dutta et al., 1998; Hou and Dutta, 2000; Suen and Spain, 1993; Suen et al., 1996). Therefore, this study documents for the first time that a recombinant nitrogen fixing soil bacterium containing introduced genes for degrading 2,4-DNT can enhance bioremediation of 2,4-DNT contaminated soil. The transfer of pJS1 (Suen and Spain, 1993) from Burkholderia sp. DNT to S. meliloti USDA 1936 was successfully performed by bacterial mating followed by selection using 2,4-DNT. Recombinants were then verified by examining for unselected antibiotic resistance markers. Furthermore, direct molecular evidence by plasmid profile analysis confirmed the presence of pJS1 in S. meliloti transconjugant DHK1 (S. meliloti (pJS1) transconjugant). Since plasmid pJS1 contains gene specifying the degradation of 2,4-DNT, we experimentally examined the transconjugant's ability to perform bioremediation in situ experiments. After testing the S. meliloti (pJS1) transconjugant symbiosis in various 2,4-DNT concentrations, it was concluded that $0.14 \mathrm{mM}$ was probably the optimal concentration to use for subsequent 2,4-DNT elimination experiments. Results of in situ experiments were interpreted as showing a significant ability of the new genetically modified $S$. meliloti transconjugant strain to degrade 2,4-DNT in spiked soil. This investigation extends our earlier studies (Hollowell et al., 1999) on the successful genetic transfer and expression of RP4::TOL megaplasmid in S. meliloti, Bradyrhizobium japonicum and B. elkanii.

The present investigation demonstrated for the first time that ARC alfalfa plants inoculated with S. meliloti (pJS1) transconjugant in soils containing $0.14 \mathrm{mM}\left(25 \mu \mathrm{g} \mathrm{g}^{-1}\right)$ 2,4-DNT had a higher plant biomass than the other treatments; whereas soil-containing $0.55 \mathrm{mM}$ $\left(100 \mu \mathrm{g} \mathrm{g}^{-1}\right)$ 2,4-DNT was clearly lethal to ARC plants. Other microorganisms have shown some capability of degrading different nitroaromatic compounds (Dutta et al., 1998), and thus affecting alfalfa growth (Toure and Dutta, 2000). Nitrite assays were performed to determine if the genetically modified $S$. meliloti would release nitrite. Negative results of nitrite release assays probably results from the nitrite having been released from 2,4-DNT being converted to nitrate by S. meliloti (Table 5) and this was used by the plants.

This study also documents the ability of S. meliloti 1936 (pJS1) transconjugant strain DHK1 in reducing 2,4-DNT by about $60 \%$ in both 0.14 and $0.28 \mathrm{mM} \mathrm{2,4-DNT} \mathrm{contami-}$ nated soil. Although $0.55 \mathrm{mM}$ 2,4-DNT contaminated soil was too toxic for plant growth, HPLC analysis of revealed that S. meliloti 1936 (pJS1) transconjugant had reduced by 
$94 \%$ the 2,4-DNT concentration, whereas there was evidently a $58 \%$ reduction produced by the parent strain USDA 1936. A previous report also showed the use of HPLC (Jackson et al., 1999) to determine the ability of soil microorganisms to degrade nitroaromatic compounds.

S. meliloti Zb57 evidently has the capability to biodegrade polychlorinated biphenyls (PCB) (Damaj and Ahmad, 1996). Labidi et al. (2001) reported recently that members of the bacterial family Rhizobiaceae including $S$. meliloti can partially degrade the nitroaromatic compound 2,4,6 trinitrotoluene. Our search analysis of the S. meliloti genome (Galibert et al., 2001) suggests that it may have dioxygenase and mono-oxygenase genes involved in biodegradation of nitroaromatic compounds (SK Dutta unpublished data). The role of a newly generated transconjugant in enhancing the biodegradation of 2,4-DNT soil using an alfalfa/microbe symbiont system is novel. Moreover, this study demonstrated for the first time highly significant reductions in various soil concentrations of 2,4-DNT by other $S$. meliloti pJS1) transconjugant strains. The presence of $0.14 \mathrm{mM}$ DNT significantly diminishes symbiosis of alfalfa with the parent strain but not with the transconjugant DHK1. This pJS1 carrying recombinant, however, was impaired in nodule formation in the absence of 2,4-DNT. Thus, we believe these findings have important implications for the genetic modification of $S$. meliloti USDA 1936 for bioremediation purposes. Improved bioremediation strains can be less effective symbiotically than their parent strains but when the toxic compound they degrade is present, they nevertheless outperform the wild-type strain both symbiotically and in terms of bioremediation.

\section{Acknowledgements}

The authors gratefully acknowledge the help of $\mathrm{Mr}$ Supriyo De in preparing this manuscript and for digital imaging. This research was partly supported by the NIH grant\#S06GM8016 and by US Army Research Grants to S. K. Dutta.

\section{References}

Alleman, B.C., Leeson, A. (Eds.), 1997. In Situ and on-Site Bioremediation, Battelle Press, Columbus, $\mathrm{OH}$.

Anderson, T.A., Coats, J.R. (Eds.), 1994. Bioremediation Though Rhizosphere Technology, American Chemical Society, Washington, DC.

Bradford, M.M., 1976. a rapid and sensitive method for the quantitation of microgram quantities of protein utilizing the principle of protein-dye binding. Analytical Biochemistry 72, 248-254.

Cole, M.A., Elkan, G.H., 1973. Transmissible resistance in penicillin G, neomycin, and chloramphenicol in Rhizobium japonicum. Antimicrobial Agents and Chemotherapy 4, 248-253.

Damaj, M., Ahmad, D., 1996. Biodegradation of polychlorinated biphenyls by rhizobia: a novel finding. Biochemistry and Biophysics Research Communications 218, 908-915.
Dandurand, L.-M.C., Knudsen, G.R., 1997. Sampling microbes from the rhizosphere and phyllosphere. In: Hurst, C.J., Knudssen, G.R., McInerney, M.J., Stetzenbach, L.D., Walter, M.V. (Eds.), Manual of Environmental Microbiology, ASM Press, Washington, DC.

Daniels, L., Hanson, R.S., Phillips, J.A., 1994. Chemical analysis. In: Gerhardt, P., Murray, R.G.E., Costilow, R.N., Nester, E.W., Wood, W.A., Krieg, N.R. (Eds.), Methods for General and Molecular Bacteriology, American Society for Microbiology, Washington, DC, pp. 514-554.

Devine, T.E., Ratcliffe, R.H., Rinker, C.M., Barnes, D.K., Ostazeski, S.A., Busbice, T.H., Hanson, C.H., Schillinger, J.A., Buss, G.R., Cleveland, R.W., 1975. Registration of 'ARC' alfalfa. Crop Science 15, 97.

Duque, E., Haidour, A., Godoy, F., Ramos, J.L., 1993. Construction of a Pseudomonas hybrid strain that mineralizes 2,4,6-trinitrotoluene. Journal of Bacteriology 175, 2278-2283.

Dutta, S.K., Jackson, M.M., Hou, L.-H., Powell, D., Tatum, H.E., 1998. Non-lignolytic TNT mineralization in contaminated soil by Phanerochaete chrysosporium. Bioremediation Journal 2, 97-103.

Galibert, F., Finan, T.M., Long, S.R., Puhler, A., Abola, P., Ampe, F., Barloy-Hubler, F., Barnett, M.J., Becker, A., Boistard, P., Bothe, G., Boutry, M., Bowser, L., Buhrmester, J., Cadieu, E., Capela, D., Chain, P., Cowie, A., Davis, R.W., Dreano, S., Federspiel, N.A., Fisher, R.F., Gloux, S., Godrie, T., Goffeau, A., Golding, B., Gouzy, J., Gurjal, M., Hernandez-Lucas, I., Hong, A., Huizar, L., Hyman, R.W., Jones, T., Kahn, D., Kahn, M.L., Kalman, S., Keating, D.H., Kiss, E., Komp, C., Lelaure, V., Masuy, D., Palm, C., Peck, M.C., Pohl, T.M., Portetelle, D., Purnelle, B., Ramsperger, U., Surzycki, R., Thebault, P., Vandenbol, M., Vorholter, F.J., Weidner, S., Wells, D.H., Wong, K., Yeh, K.C., Batut, J., et al., 2001. The composite genome of the legume symbiont Sinorhizobium meliloti. Science 293, 668-672.

Gillette, W.K., Elkan, G.H., 1996. Bradyrhizobium sp. (Arachis) strain NC92 contains two nod D genes involved in the repression of $\operatorname{nodA}$ gene required for the efficient nodulation of host plants. Journal of Bacteriology 178, 2757-2766.

Goodnight, J.H., 1982. The ANOVA Procedure, SAS User's Guide Statistics, SAS Institute, Gary, pp. 119-138.

Hanson, D., 1990. Hazardous waste: EPA adds 25 organic to RCRA list. Chemical and Engineering News 6, 4.

Hashem, F.M., Kuykendall, L.D., 1994. Plasmid DNA content of several agronomically important Rhizobium species that nodulate alfalfa, berseem clover, or Leucaena. In: Graham, P.H., Sadowsky, M.J., Vance, C.P. (Eds.), Symbiotic Nitrogen Fixation, Kluwer Academic, The Netherlands, pp. 181-188.

Hashem, F.M., Kuykendall, L.D., Bi-Padly, G.M., Devine, T., 1997. Rhizobium fredi nodulates and fixes nitrogen with Medicago sativa. Symbiosis 12, 255-264.

Hollowell, G.P., Kuykendall, L.D., Gillette, W.K., Hashem, F.M., Hou, L.-H., Tatem, H.E., Dutta, S.K., 1999. Genetic transfer and expression of RP4:TOL in Sinorhizobium meliloti, Bradyrhizobium japonicum and Bradyrhizobium elkanii. Soil Biology \& Biochemistry $31,1811-1819$.

Hou, L.H., Dutta, S.K., 2000. Phylogenetic characterization of several para PCB dechlorinating Clostridium species: 16s rDNA sequence analysis. Letters in Applied Microbiology 30, 238-243.

Itoh, Y., Watson, J.M., Haas, D., Leisinger, T., 1984. Genetic and molecular characterization of the Pseudomonas plasmid pVS1. Plasmid II, 206-220.

Jackson, M.M., Hou, L.-H., Banerjee, H.N., Sridhar, R., Dutta, S.K., 1999. Disappearance of 2,4-DNT and 2Am, 4,6-DNT by Phanerochaete chrysosporium under non-lignolytic conditions. Bulletin of Environmental Contamination Toxicology 62, 390-396.

Keith, L.H., Telliard, W.A., 1979. Priority pollutants. I. A perspective view. Environmental Science and Technology 13, 416-423.

Kummer, R.M., Kuykendall, L.D., 1989. Symbiotic properties of amino acid auxotrophs of Bradyrhizobium japonicum. Soil Biology \& Biochemistry 21, 779-782. 
Kuykendall, L.D., 1979. Transfer of R factors to and between genetically marked sublines of Rhizobium japonicum. Applied and Environmental Microbiology 37, 862-866.

Kuykendall, L.D., Elkan, G.H., 1976. Sinorhizobium japonicum derivatives differing in nitrogen-fixing efficiency and carbohydrate utilization. Applied and Environmental Microbiology 32, 511-519.

Kuykendall, L.D., Gillette, W.K., Hollowell, G.P., Hou, L.-H., Tatem, H.E., Dutta, S.K., 1997. Transfer of plasmid RP4:TOL to legume microsymbionts for soil/rhizosphere bioremediation. In: Alleman, B.C., Leeson, A. (Eds.), In Situ and On-Site Bioremediation, vol. 4. Battelle Press, Columbus, OH, pp. 65-70.

Kuykendall, L.D., Hashem, F.M., Bauchan, G.R., Devine, T.E., Dadson, R.B., 1999. Symbiotic competence of Sinorhizobium fredii on twenty alfalfa cultivars of diverse dormancy. Symbiosis 27, 1-16.

Kuykendall, L.D., Hashem, F.M., Wang, E.T., 2003. Sinorhizobium. In Brenner, K., Staley, G., (Eds.), Bergey's Manual of Systematic Bacteriology Vol 2, 2nd edition. Springer-Verlag, New york, in press.

Labidi, M., Ahmad, D., Halasz, A., Hawari, J., 2001. Bio-transformation and partial mineralization of the explosive 2,4,6-trinitrotoluene (TNT) by Rhizobia. Canadian Journal of Microbiology 47, 559-566.

Leeson, A., Alleman, B.C. (Eds.), 1999. Phytoremediation and Innovative Strategies for Specialized Remedial Applications, vol. 5, no. 6. Battelle Press, Columbus, OH.

Leonard, L.T., 1943. A simple assembly for use in the testing of cultures of Rhizobia. Journal of Bacteriology 45, 523-527.
Myrold, D.D., 1997. Quantifications of nitrogen transformations. In: Hurst, C.J., Knudssen, G.R., McInerney, M.J., Stetzenbach, L.D., Walter, M.V. (Eds.), Manual of Environmental Microbiology, ASM Press, Washington, DC, pp. 445-452.

Norris, D.O., 1964. Technique used in work with Rhizobium. Commonwealth Bureau of Pastures and Field Crops Berkshire Bulletin 47, $186-198$.

Sloger, C., 1969. Symbiotic effectiveness and $\mathrm{N}_{2}$ fixation in nodulated soybean. Plant Physiology 44, 1666-1668.

Somasegaran, P., Hoben, H.J., 1994. Handbook of rhizobia, methods in legume-Rhizobium technology, Springer, New York.

Spanggord, R.J., Spain, J.C., Nishino, S.F., Mortelmans, K.E., 1991. Biodegradation of 2,4-dinitrotoluene by a Pseudomonas sp. Applied and Environmental Microbiology 57, 3200-3205.

Suen, W.C., Spain, J.C., 1993. Cloning and characterization of Pseudomonas sp. strain DNT genes for 2,4-dinitrotoluene degradation. Journal of Bacteriology 175, 1831-1837.

Suen, W.-C., Haigler, B.E., Spain, J.C., 1996. 2,4-Dinitrotoluene dioxygenase from Burkholderia sp. strain DNT: similarity to napthalene dioxygenase. Journal of Bacteriology 178, 4926-4934.

Toure, O., Dutta, S.K., 2000. Accelerated depletion of2', 3, 4 PCB congener using combinations of the alfalfa plant and bacterial species, Hazardous Waste Research Proceeding, Kansas State University Press, Manhattan, KS, pp. 1-4. 